\title{
The Contribution of Swaziland Dairy Board on Dairy Farmers' Productivity: A Case of Mbabane Sub-Region, Swaziland
}

\author{
P. S. Masango \\ Ministry of Economic Planning \& Development, \\ Poverty Reduction, Monitoring \& Evaluation Division, \\ P.O. Box 602, Mbabane, Swaziland
}

J. I. Rugambisa \& A. S. Singh

Department of Agricultural Economics and Management,

University of Swaziland, Swaziland, P. O. Luyengo, M205, Luyengo, Swaziland

D. Kibirige (Corresponding author)

Department of Agricultural Economics and Management,

University of Swaziland, Swaziland, P. O. Luyengo, M205, Luyengo, Swaziland

E-mail: kibirige@uniswa.sz

Received: June 12, 2017

doi:10.5296/jas.v5i2.11470
Accepted: June 26, 2017

Published: June 29, 2017

URL: https://doi.org/10.5296/jas.v5i2.11470 


\section{Abstract}

The Swaziland Dairy Board (SDB) was established under the Act No. 28 of 1968 to promote increased dairy production to satisfy the domestic and export market. Despite numerous efforts of SDB through its dairy policy goals, Swaziland is failing to achieve self-sufficiency in liquid milk production, and can hardly sustain its local demand. Therefore, the study aimed at establishing the contribution of SDB policy goals on smallholder dairy farmers' productivity. Primary data was collected from 120 dairy farmers through the use of a structured questionnaire in the Mbabane sub-region. The study characterized dairy farmers as mostly male $(57 \%)$ who are aged above 55 years and married $(88 \%)$, attained secondary education(48\%) with farming experience of 4 years, milking averagely 2 cows per day, and each cow yielding averagely 10 litres and 13 litres per day for non-SDB and SDB members, respectively. The results further revealed that farmers trained by SDB were practicing more of the recommended animal husbandry practices compared to non-SDB farmers. Moreover, the SDB farmer's milk yields were higher than non-SDB farmers at $10 \%$ significant level, although SDB farmers' milk productivity is still regarded relatively low. Factors influencing productivity of milk among small holder dairy farmers included sex of the farmer, age, dairy sales incomes, number of milking cows, market distance, use of supplementary feed, dairy records keeping and the breeding system. Therefore, local milk production can increase if the stakeholders in the dairy industry can adopt SDB policy strategies, dairy related services and good livestock husbandry practices.

Keywords: Swaziland Dairy Board, dairy farmers, dairy development strategies, milk production.

\section{Introduction}

Swaziland aspires to have a viable, sustainable and competitive dairy industry to meet the demand of her population (estimated at 1,018,449 people in 2008) adequately with milk and dairy products and possibly export to other countries. Milk especially in its sour form, is a traditional source of protein for virtually all Swazi households in the country. The dairy industry in Swaziland is made of a number of role-players that include milk producers (small, medium and large scale), processors, distributors, retailers, as well as consumers. In addition, there are importers and transiters of dairy products. All these role players are regulated by the Swaziland Government mainly through the Swaziland Dairy Board which is a regulatory and statutory agent of government. (SDB, 2014).

The production of milk in Swaziland is under the auspice of the Swaziland Dairy Board (SDB) (MoA, 2013). The mandate of the SDB is to complement Government in developing and promoting the production and consumption of quality dairy products by coordinating and harmonizing all activities in the dairy industry through appropriate skills and technology (SDB, 2009). The SDB was established in 1971 under the Dairy Act No. 28 of 1968, it subsequently established a private milk handling plant in Matsapha which dominated formal milk marketing until 1999 when the plant was leased to a private company called Parmalat, in the same year, the SDB mandate became strictly regulatory rather than commercial (Comprehensive Africa Agriculture Development Programme (CAADP, 2013). 


\section{$\Lambda$ Macrothink}

The dairy sub-sector has policy objectives to enhance dairy development programmes and reduce the county's dependence on importation of liquid milk and dairy products. The aim is to increase milk production in Swaziland to a level of self-sufficiency in liquid milk supply and dairy products and possibly later to export the surplus. Although efforts are being made by Swaziland Dairy Board to ensure policy goals are achieved through programmes in place including services and good dairy husbandry practices (SDB, 2014), the country is yet to achieve the level of self-sufficiency in milk and dairy products. This has resulted in the country being a net importer of dairy products, importing millions of litres of milk from South Africa (CBS, 2015).

The major aim of the study was to analyse the contribution of Swaziland Dairy Board (SDB) on dairy famers' productivity in the Mbabane sub region. The specific objectives were to: identify the socio-economic characteristics and dairy husbandry practices by dairy farmers; analyse the level of adherence on dairy farming requirements by dairy farmers; estimate and compare milk productivity of SDB farmers with non SDB farmers; and to determine the socioeconomic factors and SDB-developed dairy husbandry practices which influence milk yield among small scale dairy farmers. The study tested the following hypothesis:

Null Hypothesis: $\mu_{1}=\mu_{2}$ There is no significant difference in milk yield between SDB farmers and Non-SDB dairy farmers.

Alternative Hypothesis: $\mu_{1} \neq \mu_{2}$ There is a significant difference in milk yield between SDB farmers and Non-SDB dairy farmers

\section{Methodology}

Swaziland is characterised by four climatic regions, namely: Hhohho, Manzini, Shiselweni and Lubombo. The study was undertaken in southern part of the Hhohho region in the, Mbabane sub region.

\subsection{Research Design}

The study used descriptive statistics to analyse the socio-economic and dairy husbandry practices. The independent t-test was used to compare milk productivity of SDB farmers with non SDB farmers and the multiple regression analysis was used to determine the relationship between milk productivity, and socioeconomic characteristics and dairy husbandry practices of dairy farmers.

\subsection{Target Population}

The target population was dairy farmers residing in the Mbabane sub region. The total number of dairy farmers was three thousand eight hundred and five (3805), of these one hundred and twenty five (125) were SDB farmers and three thousand six hundred and eighty (3680) were non-SDB farmers (MoA, 2014). The sample size of 120 dairy farmers was attributed by thirty eight (38) were SDB farmers and eighty two (82) were non-SDB farmers. 


\subsection{Sampling Procedure}

Simple random sampling techniques were used for selection of dairy farmers in the study areas. Swaziland Dairy Board development officials provided the list of dairy farmers registered with their institution (SDB farmers).

The Assistant Veterinarians office provided a list of all dairy farmers residing in the Mbabane Sub-region (non SDB farmers), hence the sample size of 120 dairy farmers, of which thirty eight (38) were SDB farmers and eighty two (82) were non SDB farmers

\subsection{Data Collection Procedures}

Face-to-face interpersonal interviews were conducted through pre-tested questionnaire for primary data collection. The corrections and suggestions from dairy experts were used to modify research questions.

Respondents were asked structured open ended questions in a narrow funnel sequence allowing them to elaborate on issues as much as possible, thus both qualitative and quantitative data were collected. The research questionnaire was prepared in English and translated in the local language during interviews.

\subsection{Data Analysis}

The data were captured using Statistical Package for Social Scientists version 20 and analysed using descriptive statistics, inferential statistics and multi-variate regression analysis models.

To identify and compare dairy farmers' socio-economic and dairy husbandry practices of SDB and non SDB farmers descriptive statistics (means, frequencies and cross-tabulations) and chi-square values were generated. The independent t-test was used to estimate and compare milk productivity of SDB farmers with non SDB farmers to find out whether there were significant differences between the two independent samples.

The test statistic was defined by the following equation.

$$
\begin{aligned}
& \mathrm{t}=\left(\overline{X_{1}}-\overline{X_{2}}\right) /\left[\left(\mathrm{s}_{1} / \mathrm{n}_{1}\right)+\left(\mathrm{s}_{2} / \mathrm{n}_{2}\right)\right]^{0.5} \\
& \text { where }: \overline{x_{1}}-\text { is the mean yield of SDB dairy farmers } \\
& \overline{x_{2}} \text {-is the mean yield of non SDB dairy farmers } \\
& \mathrm{n}_{1}-\text { is the sample size of SDB dairy farmers. } \\
& \mathrm{n}_{2} \text { - is the sample size for non SDB dairy farmers } \\
& \mathrm{s}_{1}-\text { Standard error of the mean for SDB dairy farmers } \\
& \mathrm{s}_{2}-\text { Standard error of the mean for non SDB dairy farmers }
\end{aligned}
$$

To determine factors which influenced milk yield an ordinary least squares (OLS) regression analysis was run for milk yield against socioeconomic, marketing and dairy cattle husbandry 


\section{IIMacrothink}

practices variables in the study. Three regression models were run because one of the limitations of multiple regression is that when you plug in many predictor variables, few estimates become significant and the regression line very unstable (Gujarati, 2009).

The first empirical model was related to socioeconomic characteristics of farmers and presented as:

$$
\begin{aligned}
& Y_{i}=\beta_{0}+\beta_{1} X_{1}+\beta_{2} X_{2}+\beta_{3} X_{3}+\beta_{4} X_{4}+\beta_{5} X_{5}+\mu \\
& \text { where: } \\
& \qquad \begin{array}{l}
Y_{i}=\text { total milk yield in litres per cow/day in a farm } \\
X_{1}=\text { sex of the dairy farmer }\{\text { where: male (1), female (2) }\} \\
X_{2}=\text { age of the dairy farmers in completed years } \\
X_{3}=\text { marital status }\{\text { where: married (1) single (2) and widowed (3) }\} \\
X_{4}=\text { education level attained by the dairy farmer }\{\text { where: never been (1), } \\
\text { primary (2), secondary (3) and tertiary (4) }\} \\
X_{5}=\text { family size of the dairy famer }
\end{array}
\end{aligned}
$$

The second empirical model was related to milk productivity and the economic aspect of farmers is presented as:

$$
\begin{aligned}
& Y_{i}=\beta_{0}+\beta_{1} X_{1}+\beta_{2} X_{2}+\beta_{3} X_{3}+\beta_{4} X_{4}+\beta_{5} X_{5}+\beta_{6} X_{6}+\mu \\
& \text { where: } \\
& Y_{i}=\text { total milk yield in litres per cow/day in a farm } \\
& \qquad X_{1}=\text { dairy farmers' years' experience in dairying } \\
& \quad X_{2}=\text { monthly dairy income } \\
& \quad X_{3}=\text { number of cows milked per day } \\
& \quad X_{4}=\text { price of one litre fresh milk } \\
& \quad X_{5}=\text { location of dairy market }\{\text { where: farm gate (1), local market (2), } \\
& \text { other traders (3) }\} \\
& X_{6}=\text { distance to dairy market }
\end{aligned}
$$

The third empirical model was related to milk productivity and animal husbandry practices and is presented as:$$
\mathrm{Y}_{\mathrm{i}}=\beta_{0}+\beta_{1} X_{1}+\beta_{2} \mathrm{X}_{2}+\beta_{3} \mathrm{X}_{3}+\beta_{4} \mathrm{X}_{4}+\beta_{5} \mathrm{X}_{5}+\beta_{6} \mathrm{X}_{6}+\beta_{7} \mathrm{X}_{7}+\beta_{8} \mathrm{X}_{8}+\mu
$$$$
\text { where: }
$$ 
$\mathrm{Y}_{\mathrm{i}}=$ total milk yield in litres per cow/day in a farm

$\mathrm{X}_{1}=$ pasture planting $\{$ where: yes (1), no (2) \}

$\mathrm{X}_{2}=$ use of supplementary feed $\{$ where: yes (1), no (2), sometimes (3) $\}$

$\mathrm{X}_{3}=$ feeding scheme used $\{$ where: stall feeding (1), grazing (2), both (3)

$\mathrm{X}_{4}=$ training on dairy practices $\{$ where: yes (1), no (2) $\}$

$\mathrm{X}_{5}=$ keeping of dairy records $\{$ where: yes (1), no (2) $\}$

$\mathrm{X}_{6}=$ breeding system $\{$ where: artificial insemination (1), natural bull service (2) $\}$

$\mathrm{X}_{7}=$ use of appropriate milking equipment $\{$ where: yes (1), no (2) $\}$

\section{Findings and Discussion}

\subsection{Social Characteristics of Dairy Farmers}

The results presented in Table 1 show that the overall sex distribution of dairy farmers was about $57 \%$ male and $43 \%$ female. The distribution of males and females of SDB farmers was the same, implying that there were no gender disparities. However, the sex distribution of non SDB farmers showed that there were more male dairy farmers (about $63 \%$ ) than female dairy farmers (about $37 \%$ ). The overall sex disparity in the dairy industry was found to be approximately $20 \%$ between males and female. This shows that the country has made marginal strides in breaking the cultural barrier which prevented women from possessing cattle in the family. In the past centuries, cattle were a sign of a man's wealth and communities reserved grazing land for farmers. However, these results differ from a study carried out by the Kenyan Research institute (2012), which found out that there is relatively high proportion of women household heads who owned dairy.

Table 1. Demographic characteristics of dairy farmers

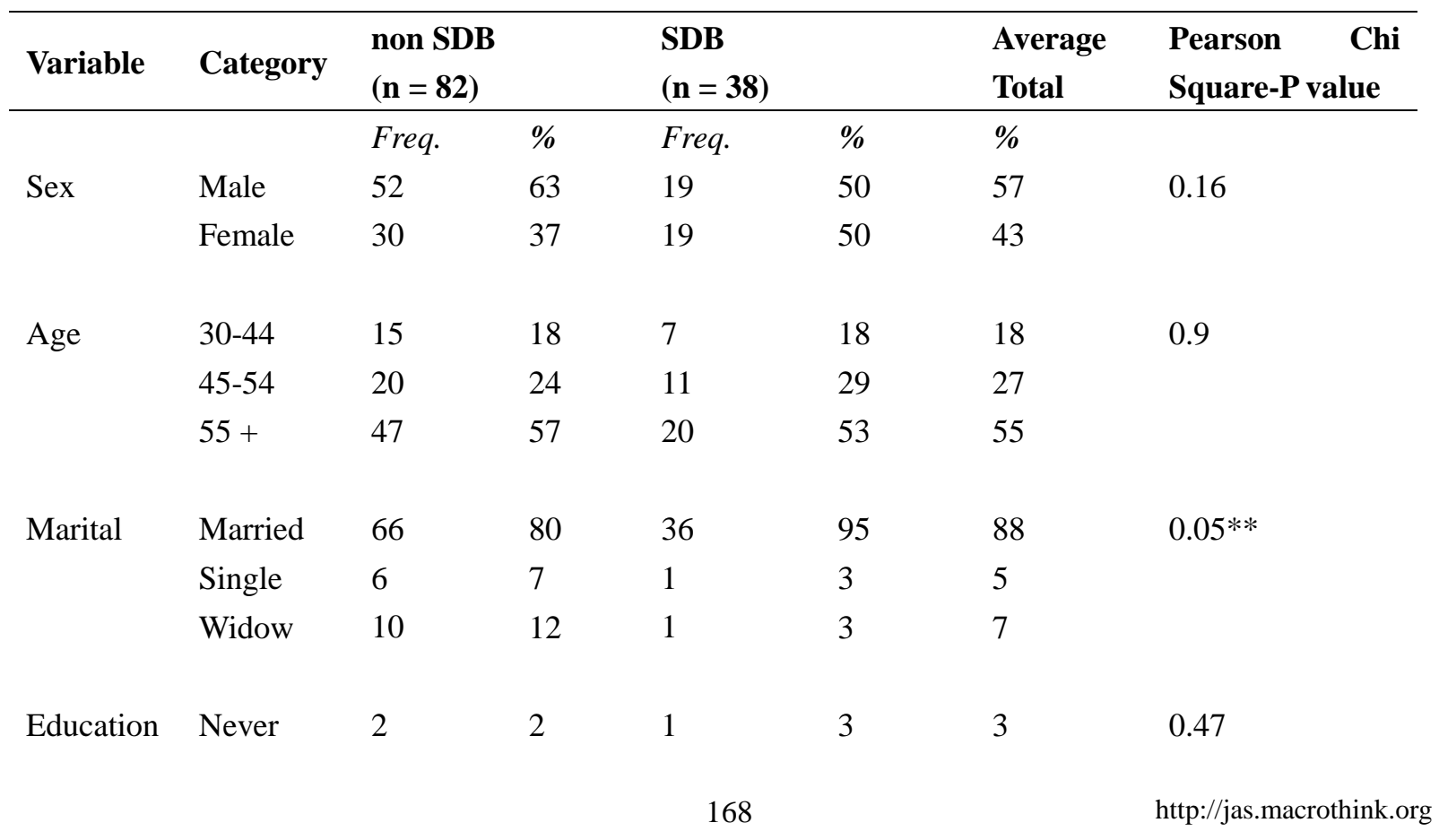




$\begin{array}{llllll}\text { Primary } & 18 & 22 & 5 & 13 & 18 \\ \text { Secondary } & 40 & 49 & 18 & 47 & 48 \\ \text { Tertiary } & 22 & 27 & 14 & 37 & 32\end{array}$

\begin{tabular}{llllllll} 
Family & $0-4$. & 16 & 20 & 12 & 32 & 26 & 0.56 \\
size & $5-9$. & 54 & 66 & 24 & 63 & 65 & \\
& $10+$ & 12 & 15 & 2 & 5 & 10 & \\
\hline
\end{tabular}

Where: $* *=5 \%$ significance level;

Freq. $=$ frequency .

Cattle ownership in Swaziland was culturally associated with age, that is, as one grows older, chances of cattle possession are increased. The results showed that most (about $55 \%$ ) dairy farmers' age was above 55 years, these were followed by the $(45-54)$ years' age cohort at around $27 \%$. The last and least (about $18 \%$ ) age group of dairy farmers were those between (30 - 44) years. The results suggest that most daily farmers are aging with less youth participating in this sector. This exposes the industry to declining daily productivity because it is labour intensive and as the farmers' grows older, their energy to carry out the hard tasks diminishes. Based on the researcher's observation, farming is perceived as a retirement occupation for both psychosocial satisfaction and income generation in Swaziland.

The role of wives, children and family elders in participation and assistance in dairy production activity is important. Family members support each other in making and achieving crucial farming decision. Considering the overall sample, the study revealed that an averagely of $88 \%$ of the dairy farmers were married, this comprises of approximately $80 \%$ non SDB farmers and approximately $95 \%$ SDB farmers. The proportion of widowed dairy farmers was about $7 \%$ and of those who were single, either due to separation or were never married was about $5 \%$. Results further indicate that there were more married SDB farmers (about $95 \%$ ) than non-SDB farmers (about $80 \%$ ), and less single among SDB farmers (about $3 \%$ ) compared to non-SDB farmers (about12\%) less at approximately $5 \%$ significant level.

Education is thought to play a big role in farming especially in the adoption of new technologies, trainings and putting in practice knowledge gained. The overall results showed that most dairy farmers (about $48 \%$ ) had secondary school education attainment, these were closely followed by those with tertiary education at about $32 \%$ dairy farmers , about $18 \%$ dairy farmers had attained primary school education and about $3 \%$ had never attended school. Further analysis showed that more non SDB farmers (about $22 \%$ ) had primary education compared to SDB farmers (about $13 \%$ ) and more SDB farmers (about $37 \%$ ) had tertiary education compared to non SDB farmers (about $27 \%$ ). The analysis revealed that most dairy farmers qualified to operate this industry even those with minimum education level like primary school certificate holders. However, the study suggests that most educated dairy farmers are highly likely to seek advice and guidance from SDB.

Household size sometimes in village setting is known to be a source of labour for farm and off-farm income generating activities (Sentumbwe, 2007). The results showed that most dairy farmers (about $65 \%$ ) had a family size ranging between 5 and 9 family members per 


\section{Macrothink}

household. These were followed by dairy farmers with 1 to 4 family members who constituted approximately $26 \%$ of the sampled dairy farmers. The least family size dairy farmer comprised of above 10 family members in a household, this comprised about $10 \%$ of the population of the sampled dairy farmers. In addition, it was found that more SDB farmers (about $32 \%$ ) had a family size ranging between 1 and 4 family members compared to non SDB farmers who had about $20 \%$ families with the same category of family members. On the other hand, more non SDB famers (about $15 \%$ ) had a family size of above10 members compared to SDB farmers who constituted of about $5 \%$ of the sampled size. The results suggest that non SDB farmers on average had a higher family size than SDB farmers. It can be noted that family size cannot imply family labour because it may include school going children.

\subsection{Commercial Characteristics of Dairy Farmers}

These are a set of independent variables related to the performance of business activities involved in the flow of dairy products which were asked to dairy farmers. Table 2 shows a summary of the responses.

Table 2. Commercial characteristics of dairy farmers

\begin{tabular}{|c|c|c|c|c|c|c|c|}
\hline Variable & Category & $\begin{array}{l}\text { Non } \\
\text { farmer }\end{array}$ & SDB & \multicolumn{2}{|c|}{ SDB farmer } & \multirow{2}{*}{$\begin{array}{l}\text { Average } \\
\text { Total }\end{array}$} & $\begin{array}{l}\text { Pearson } \\
\text { Chi-Square } \\
\text { P Value } \\
\end{array}$ \\
\hline & & Freq. & $\%$ & Freq. & $\%$ & & \\
\hline \multirow[t]{3}{*}{ Farm experience } & $0-4$ years & 41 & 50 & 24 & 63 & 57 & 0.626 \\
\hline & 5 - 9 years & 18 & 22 & 9 & 24 & 23 & \\
\hline & $10+$ & 23 & 28 & 5 & 13 & 21 & \\
\hline \multirow[t]{3}{*}{ Milking cows } & $1-3$ cows & 55 & 67 & 30 & 79 & 73 & 0.561 \\
\hline & $4-9$ cows & 23 & 28 & 7 & 18 & 23 & \\
\hline & $10+$ & 4 & 5 & 1 & 3 & 4 & \\
\hline \multirow[t]{3}{*}{ Price of fresh milk } & E1 - E8 & 15 & 18 & 4 & 11 & 14 & $0.066^{*}$ \\
\hline & E9 - E10 & 61 & 74 & 31 & 82 & 78 & \\
\hline & E11+ & 6 & 7 & 3 & 8 & 8 & \\
\hline \multirow[t]{6}{*}{ Milk yield per day } & $1-7.5$ & 26 & 32 & 7 & 18 & 25 & $0.075^{*}$ \\
\hline & $7.6-10.0$ & 26 & 32 & 4 & 11 & 21 & \\
\hline & $10.1-12.5$ & 12 & 15 & 8 & 21 & 18 & \\
\hline & $12.6-15.0$ & 13 & 16 & 12 & 32 & 24 & \\
\hline & $16+$ & 5 & 6 & 7 & 18 & 12 & \\
\hline & $0-5000$ & 34 & 41 & 15 & 39 & 40 & 0.780 \\
\hline \multirow{3}{*}{$\begin{array}{l}\text { Monthly } \\
\text { income }\end{array}$} & $<10000$ & 23 & 28 & 14 & 37 & 32 & \\
\hline & $<15000$ & 12 & 15 & 4 & 11 & 13 & \\
\hline & $15001+$ & 13 & 16 & 5 & 13 & 15 & \\
\hline
\end{tabular}




\begin{tabular}{llllllll} 
Dairy markets & farm gate & 57 & 70 & 27 & 71 & 70 & 2.320 \\
& $\begin{array}{l}\text { traders } \\
\text { market }\end{array}$ & 0 & 0 & 1 & 3 & 1 & \\
Distance to market & $0-9 \mathrm{~km}$ & 68 & 30 & 10 & 26 & 28 & \\
& $10-19 \mathrm{~km}$ & 8 & 10 & 8 & 21 & 15 & $0.08^{*}$ \\
& $20+$ & 6 & 7 & 3 & 8 & 8 & \\
\hline
\end{tabular}

Where: * equals $10 \%$ level of significance, Freq.= means frequency, $\%=$ percentage

The study revealed that most dairy farmers (about $57 \%$ ) had between 1 and 4 years' experience in dairy farming. Those with 5 to 9 years' experience in dairy farming were about $23 \%$ of the sampled population, and those who had been practicing dairy farming for more than 10 years were about $21 \%$ of the dairy farmers. Further analysis showed that more SDB farmers (about $63 \%$ ) had between 1 and 4 years' experience in dairy farming while, about $50 \%$ non SDB had between 1 and 4 years' experience in dairy farming. On the other hand more non SDB dairy farmers (about $28 \%$ ) were found to have practiced dairy farming for more than 10 years compared to SDB farmers (about $13 \%$ ). The results show a sudden shoot in the number of SDB dairy farmers over the past 4 years, this thought to suggest that SDB has engaged new advocacy and support strategies which have attracted more people to join the dairy industry.

The results presented in Table 2 indicate that most dairy farmers (about $73 \%$ ) milked between 1 and 3 cows per day. Few dairy farmers milked more than 10 cows per day (about $4 \%$ ). In comparison, the analysis showed that more SDB farmers (about $79 \%$ ) milked between 1 and 3 dairy cows per day than non-SDB farmers (about $63 \%$ ). Further analysis indicated that more non-SDB farmers (28\%) milked above 4 cows per day compared to SDB farmers $(18 \%)$ who were milking the same number of cows. This is thought to suggest that non-SDB farmers had more milking cows than SDB farmers. However, the number of cows milked per day was dictated by the type of breed, with non-SDB farmers preferring relatively cheaper and affordable cross breeds (exotic-Nguni breed) compared to relatively expensive and fewer exotic breeds (Jersey and Friesian breeds) reared by SDB farmers.

The study indicated that dairy farmers were price setters in the industry. They also held the decision to sell to any clients along the supply chain. Government in an effort to catalyse and improve the dairy industry, established a processing plant which buys milk from dairy farmers at E4.50 per litre according to SDB annual report (2015). The national milk processing plant is situated in the industrial hub of the country at the Matsapha. The results showed that the farm gate price of fresh milk among most dairy farmers (about $78 \%$ ) was between E9.00 and E10.00 per litre. About $14 \%$ dairy farmers sold milk for E4.00 E8.00per litre and about $8 \%$ dairy farmers sold milk at a price from E11.00 and above. A further analysis showed that the prevailing market price for 1 litre of fresh milk was E10 which is charged by $66 \%$ of the dairy farmers and a few farmers (about $6 \%$ ) sold milk at E12. The Pearson chi-square test indicated a slightly significant (10\% level) difference in milk prices between SDB and Non-SDB famers, as $90 \%$ of SDB farmers enjoyed prices above E9 per litre compared to the $81 \%$ farmers who charged the same price. 


\section{Mll Macrothink}

Journal of Agricultural Studies

ISSN 2166-0379

2017, Vol. 5, No. 2

The results also showed the extreme cases such as, the lowest milk selling price was E4.50 to Parmalat and the highest price was E12.00 at farm gate. The study found that most dairy farmers were not willing to sell their dairy products to Parmalat because of the low buying price, ceteris paribus. During interviews, the researcher found out that Parmalat buys milk from South African farmers at a price of E3.00 per litre and buys milk from Swazi farmers at E4.50 per litre. This implies that South Africa has a comparative advantage in the production of milk because of relatively high technology in the dairy sector compared to Swaziland.

Peak milk is defined as the highest recorded milk production in a cow's first 150 days (Litherland, 2011). The study estimated average milk yield received by dairy farmers on a daily basis. The results showed that most dairy farmers (about $24 \%$ ) produced between 1 and 7.5 litres of milk per day, few dairy farmers (about $12 \%$ ) produced more than 16 litres of milk per day. Furthermore, most non-SDB farmers (about $64 \%$ ) produced between 1 and 10 litres per day, while most SDB farmers produced between 10 and 15 litres milk per day. The result suggests that even though SDB dairy farmers milked few cows they produced more milk than non SDB farmers. The difference may be related to services provided by SDB and differences in the breeds. Based on the Pearson chi-square test, the SDB farmers significantly produced more milk than non-SDB farmers at $10 \%$ level of significance.

Monthly dairy income was estimated and results showed that most dairy farmers (about $40 \%$ ) earned approximately E5,000 per month this was made up by approximately $41 \%$ non SDB and about $39 \%$ SDB farmers. Few dairy farmers (approximately $7 \%$ ) earned between 10,000 and E15,000 per month. In addition, more non SDB farmers (31\%) earned above E10,000 per month compared to SDB farmers (24\%). Therefore the results suggest that non SDB farmers earned more than SDB farmers this may be attributed by the fact that non-SDB farmers had more cows than SDB farmers.

The study wanted to establish the source of dairy markets of farmers. The results showed that about $70 \%$ dairy farmers sell their produce at the farm gate, about $28 \%$ dairy farmers sell their produce to nearby community markets and $1 \%$ dairy farmers sell through the middle-man. The analysis indicated that on average $70 \%$ of both SDB and non SDB sold at the farm gate and approximately $26 \%$ of both SDB and non SDB farmers sold to community markets. These findings indicate that irrespective of membership to SDB, dairy farmers' marketing channels are the same. This may ease intervention of addressing farmers' challenges related to marketing of their products collectively.

The distance travelled by the dairy farmers to sell dairy produce was of interest to highlight transport costs related to operating the industry. The results showed that most dairy farmers (about $77 \%$ ) travel less than 9 kilometres to sell their dairy produce. This constituted of about $83 \%$ non SDB and about $71 \%$ SDB farmers. Few (about $8 \%$ ) dairy farmers travelled more than 20 kilometres when going to sell dairy produce. Further, analysis revealed that most dairy farmers did not incur transport costs when selling dairy produce because they sold dairy produce at the farm gate, hence incurred inputs related costs. As a result, during the interviews most dairy farmers suggested that dairy feed should be sold at sub regional level, not only in the main cities and towns and Government should increase 
subsidies of dairy inputs. The Pearson Chi-square results indicate that the SDB farmers travelled the longest distance to sell their milk compared to Non-SDB farmers. According to the researcher's observation, most SDB farmers are employed in the formal sector mainly located in cities, and they travel with their milk to be sold nearby their workplaces.

\subsection{Animal Husbandry Practices of Dairy Farmers}

According to the Dairy Educator Mathew, Hann (2014), whether you grew-up on the farm and are taking over ownership from your parents or grandparents, there are some things you need to know before you get started in the dairy sector.

The feeding method was important because it was thought to contribute to increased production levels. SDB dairy development officers recommended the stall feeding practice. Dairy farmers were asked which feeding practice they implemented, that is, do they send dairy cows to graze in the communal land with other animals, or are the animals kept in a fenced enclosure which is stall feeding. The results showed that on average $53 \%$ of the dairy farmers practiced both stall feeding and grazing, about $26 \%$ of the dairy farmers practiced only grazing feeding method and about $20 \%$ dairy farmers practiced stall feeding method. The analysis revealed that more non-SDB farmers (about $67 \%$ ) practiced both feeding schemes compared to SDB farmers (about $39 \%$ ). On the other hand, more SDB farmers (about $37 \%$ ) practiced stall feeding than non SDB farmers (about $4 \%$ ). The results show that there is relatively low adherence to practicing only stall feeding dairy farming system (about $20 \%$ adherence). Moreover, the Chi-Square test indicated that more SDB farmers were practicing stall feeding than non-SDB farmers at $1 \%$ significant level.

The following Table illustrates animal husbandry practices.

Table 3. Animal Husbandry Practices of Dairy Farmers

\begin{tabular}{|c|c|c|c|c|c|c|c|}
\hline \multirow[t]{2}{*}{ Variable } & \multirow[t]{2}{*}{ Category } & \multirow{2}{*}{$\begin{array}{l}\begin{array}{l}\text { Non } \\
\text { farmer }\end{array} \\
\text { Freq. }\end{array}$} & SDB & \multicolumn{2}{|c|}{$\begin{array}{l}\text { SDB } \\
\text { farmer }\end{array}$} & \multirow{2}{*}{$\begin{array}{l}\text { Average } \\
\text { Total }\end{array}$} & \multirow[t]{2}{*}{$\begin{array}{l}\text { Pearson } \\
\text { Chi-Square } \\
\text { P-value } \\
\end{array}$} \\
\hline & & & $\%$ & Freq. & $\%$ & & \\
\hline \multirow[t]{3}{*}{ Feeding scheme used } & Stall feeding & 3 & 4 & 14 & 37 & 20 & $0.000 * * *$ \\
\hline & Grazing & 24 & 29 & 9 & 24 & 26 & \\
\hline & Both & 55 & 67 & 15 & 39 & 53 & \\
\hline \multirow[t]{3}{*}{ Supplements feed } & yes & 28 & 34 & 25 & 66 & 50 & $0.010 * * *$ \\
\hline & no & 20 & 24 & 5 & 13 & 19 & \\
\hline & sometimes & 34 & 41 & 8 & 21 & 31 & \\
\hline \multirow[t]{3}{*}{ Planted pasture } & yes & 13 & 16 & 20 & 53 & 34 & $0.000 * * *$ \\
\hline & no & 69 & 84 & 18 & 47 & 66 & \\
\hline & Artificial & & & & & & \\
\hline Breeding system & Insemination & 3 & 4 & 31 & 82 & 43 & $0.000 * * *$ \\
\hline
\end{tabular}




\begin{tabular}{lllllllll} 
& Natural bull & 79 & 96 & 7 & 18 & 57 & \\
Milking containers & & yes & 12 & 15 & 33 & 87 & 51 & $0.000^{* * *}$ \\
& no & 70 & 85 & 5 & 13 & 49 & \\
Dairy record keeping & yes & 23 & 28 & 26 & 68 & 48 & $0.000^{* * *}$ \\
& no & 59 & 72 & 12 & 32 & 52 & \\
trained on dairy & & & & & & & \\
& yes & 10 & 12 & 33 & 87 & 50 & $0.000^{* * * *}$ \\
& no & 72 & 88 & 5 & 13 & 50 & \\
\hline
\end{tabular}

Where $* * *=$ significant difference at $1 \%$ level; Freq $=$ frequency; $\%=$ percentage

Good quality feed play an important role in cutting down costs of using concentrates which would be needed to make -up for poor forages (Dairy Requirements for Starting a dairy enterprise, 2000). Dairy farmers were also asked how often they gave concentrates to their animals and respective quantities per day. Concentrates are mainly sources of energy and protein, but they usually also contain minerals and other important nutritional requirements that cannot be met from forage alone (SDB, 2000). The results showed that on average $50 \%$ dairy farmers used dairy feed consistently as per the dairy requirements, about $31 \%$ dairy farmers occasionally used dairy feed and about $19 \%$ did not use supplementary feed. In addition, more non SDB farmers (41\% on average) were inconsistent in their feeding practice compared to SDB farmers (about $21 \%$ ). Some farmers stated that they often gave dairy concentrate when the milk volume is low and stopped when milk levels improved, others have succumbed to giving dairy concentrate once a day instead of twice. Concerning supplementary feeding, more SDB farmers (around $66 \%$ ) practiced it compared to non SDB farmers (approximately $34 \%$ ) significantly at $1 \%$ level.

Another dairy requirement is that dairy farmers should plant pasture to ensure constant availability of animal feed. Dairy farmers were asked if they planted pasture for their dairy cows. The results showed that approximately $66 \%$ of the dairy farmers did not grow pasture, this constitutes of about $84 \%$ non-SDB farmers and about $47 \%$ SDB farmers. The analysis also showed that more SDB farmers (about $53 \%$ ) planted fodder for their animals compared to non SDB farmers that was at about $16 \%$, and hence a significant difference in the number of farmers participating in planting pasture at $1 \%$ level. This analysis suggests that there is need to improve initiatives aimed towards encouraging dairy farmers to plant animal fodder.

Dairy cattle breeding are important for reproduction of good quality dairy cows. According to Morel (2013), Artificial Insemination was originally developed to control the spread of disease, by avoiding the transport of animals with potential pathogens to other animal units for mating and by avoiding physical contact between individuals. In the study dairy farmers were asked which breeding method they use to ensure strong genes and production of high volumes of milk. The results revealed that approximately $43 \%$ dairy farmers practiced artificial insemination and approximately $57 \%$ of dairy farmers used the natural bull for breeding. Furthermore, the findings showed that most (about $96 \%$ ) non-SDB dairy farmers 
used the natural bull service breeding method, while, most (about $82 \%$ ) SDB farmers preferred artificial insemination breeding method, and this comparison was found to be significant at $1 \%$ level.

According to the SDB Requirements for Starting a Dairy Enterprise (2000), all persons involved in the handling of milk and dairy products must be well trained in milk hygiene. Hygienic milk handling involves using clean containers, maintaining a clean milking environment and observing good personal hygiene. Use of appropriate containers is also very important and only metal containers made of aluminum and stainless steel cans are recommended.

The results revealed that approximately $51 \%$ dairy farmers used milking cans made of steel, and on average $41 \%$ used plastic containers. The analysis showed that about $86 \%$ SDB farmers used the recommended milking containers and about $15 \%$ non-SDB farmers used the correct milking equipment, hence, a significant difference in the number of farmers using milking containers at $1 \%$ level. Concerning the use of incorrect milking containers, the analysis showed that about $85 \%$ non SDB farmers and approximately $13 \%$ SDB farmers used incorrect milking containers. From the findings one would commend the SDB for properly advocating this requirement and would recommend the national veterinary office to adopt the same practice.

Without written records, farmers have to depend on their memory when making decisions to transform their farm practices. Thus record keeping is of paramount importance since the memory is unreliable. This was another requirement for starting a dairy enterprise, thus farmers were asked whether they kept records on farm inputs and outputs. The results showed that approximately $48 \%$ dairy farmers kept farm records of all farming activities and about $52 \%$ dairy farmers did not keep dairy records. The analysis showed that approximately $72 \%$ non-SDB farmers and about $32 \%$ SDB farmers did not keep dairy farm records. On the other hand, about $28 \%$ non SDB farmers and about $68 \%$ SDB farmers kept dairy farm records, an indication of a significant difference at $1 \%$ level.

Most Swazi households have cows and taking care of cattle is a normal household core, however, taking care of a dairy cow requires some skill. Hence dairy farmers were asked if they had undergone any training on dairy farm practices. The results showed that approximately $48 \%$ dairy farmers were trained on dairy farm practices. The analysis showed that about $87 \%$ SDB dairy farmers were trained on dairy farming practices and about $13 \%$ SDB farmers were not trained, most of these were beneficiaries like widows and other family members who acquired ownership of dairy cows. The findings revealed that most SDB farmers (about $87 \%$ ) were trained on dairy management practices while about $88 \%$ non SDB farmers were not trained, hence, a significant difference of $1 \%$ level. From the analysis, one would recommend that Government veterinary officials should prepare capacity building forums for dairy farmers. 


\subsection{Test for Independency of Means}

The independent t-test was undertaken to compare whether the two groups (SDB farmer and non SDB farmers) had different mean values of milk yields and the following results were revealed. The mean milk yield for Non-SDB farmer was 9.90 while the mean milk yield for SDB farmer was 12.51. The mean difference in milk yields between the two groups is 2.6 liters per cow per day. The standard deviation was 3.78 for non SDB farmers and 4.28 litres for SDB farmers. The sample size of non SDB farmers was 82 and 38 for SDB farmers as illustrated in Table 4 below.

Table 4. Student T-Test of Independent Means

\begin{tabular}{|l|l|l|l|l|l|l|}
\hline & SDB Farmer & N & Mean & $\begin{array}{l}\text { Std. } \\
\text { Deviation }\end{array}$ & $\begin{array}{l}\text { Mean } \\
\text { difference }\end{array}$ & P-Value \\
\hline \multirow{2}{*}{ Milk yield } & Non SDB farmers & 82 & 9.90 & 3.78 & -2.6 & 0.001 \\
\cline { 2 - 7 } & SDB farmers & 38 & 12.51 & 4.28 & & \\
\hline
\end{tabular}

There was a significant difference in milk yields among the two groups at $1 \%$ level, thus, rejected the null hypothesis that there is no significant difference in milk yield between SDB farmers and Non SDB Dairy farmers at approximately $95 \%$ confidence interval and conclude that SDB significantly contributes to milk production in the country. These results suggest that the SDB policy goals were being achieved through the training programs though the yields are still low compared with the recommended average milk yields of 15 liters per dairy cow per day during interviews with the SDB staff.

\subsection{The Multiple Regression Analysis}

Multiple regression analysis was run to determine if there was a relationship between the dependent variable which is the daily milk yield on the farm and the independent variables which were demographic, commercial and dairy cattle husbandry practices. The multiple regression analysis results related to the relationship between milk yield and demographic characteristics are summarised in the Table 5.

According to results presented in Table 5, sex and age were the only variables that had a significant relationship with milk yields per day at $10 \%$ and $5 \%$ level, respectively, age being negative and sex being positive. These results suggest that a unit increase in the number of male participating in dairy farming results in an increase of 1.4 litres of milk yield per day, while a unit increase in farmers' age by one year results in a decrease of 0.51 litres of milk per day.

The results showed that the following independent variables negatively influenced milk yield, these were namely; sex, age of the dairy farmer, monthly dairy income, number of cows milked per day, distance to the dairy market, use of supplementary feed, keeping of dairy records and breeding system, therefore policy direction should be aimed towards addressing these factors in the short term. This means that as the farmer grows older the productivity 
level decreases on the farm.

Table 5. Analysis of the influence of farmers' demographic, marketing and dairy cattle husbandry practices on milk yield

\begin{tabular}{lllll}
\hline Variable & Coefficients & Std. Error & t & P-Values \\
\hline
\end{tabular}

Model 1: Analysis of the influence of farmers' demographic characteristic on milk yield

$\begin{array}{lllll}\text { Sex } & 1.405 & 0.784 & 1.791 & 0.076^{*} \\ \text { Age } & -0.514 & 0.225 & -2.289 & 0.024^{* *} \\ \text { Marital status } & 0.114 & 0.393 & 0.290 & 0.772 \\ \text { Education } & 0.117 & 0.317 & 0.369 & 0.713 \\ \text { Family size } & -0.101 & 0.121 & -0.835 & 0.405\end{array}$

Model 2: Analysis of the influence of farmers' commercial characteristic on milk yield

$\begin{array}{lllll}\text { Years in dairy } & -0.081 & 0.053 & -1.536 & 0.127 \\ \text { Monthly dairy income } & 2.632 & 0.450 & 5.843 & 0.000^{* * *} \\ \text { Milking cows } & -1.185 & 0.182 & -6.514 & 0.000^{* * *} \\ \text { Dairy markets } & -0.459 & 0.459 & -0.999 & 0.320 \\ \text { Distance to market } & 1.102 & 0.573 & 1.923 & 0.057^{*}\end{array}$

Model 3: Analysis of the influence of dairy cattle husbandry practices on milk yield

\begin{tabular}{lllll} 
Planted pasture & -0.481 & 0.870 & -0.553 & 0.581 \\
Supplementary feed & -1.322 & 0.386 & -3.424 & $0.001^{* * *}$ \\
Feeding scheme used & 0.528 & 0.507 & 1.042 & 0.300 \\
Trained on dairy & -0.605 & 1.096 & -0.552 & 0.582 \\
Records on dairy & -1.576 & 0.775 & -2.033 & $0.044^{* *}$ \\
Breeding system & -1.857 & 1.020 & -1.821 & $0.071^{*}$ \\
Milking equipment & 0.046 & 0.247 & 0.187 & 0.852 \\
\hline
\end{tabular}

where: $*, * *, * * *=$ significant at $10 \%, 5 \%$ and $1 \%$ level; Std Error $=$ Standard Error

The study showed that most dairy farmers are aged from 50 years onwards, at this time in life most peoples' health and physical strength is frail. Dairy farming is a labour intensive activity that need strong and healthy people. Hence the need to attract younger energetic people into the dairy industry.

The results presented in Table 5 regarding the regression analysis to determine the relationship between farmers' marketing characteristics and milk yield indicate that there is a significantly positive relationship between milk yield and monthly dairy income. An increase 
by one lilangeni of the monthly dairy income resulted in an increase of about 2.632 litres of milk produced per day. This suggests that most dairy farmers reinvest their incomes accrued to the dairy enterprise in dairy farming. The amount of monthly income is dependent on the daily milk yield, in that, when it is low, then the monthly income will be low, but, when the daily milk yield improves the farmer enjoys higher returns.

Milk yield and number of cows milked per day were negatively related, that is, an increase by one dairy cow milked per day resulted in a decrease of about 1.185litres of milk yield each day. This can be attributed to the higher number of non-SDB farmers sampled compared with SDB farmers. The non-SDB farmers rear cross-breeds (Nguni-exotic breeds) which yield less milk compared to the exotic dairy cattle breeds which yield more milk. The research found that most SDB farmers had dairy cows which produced high volumes of milk an average of 16 litres per day per cow while the Nguni produced an average of 7 litres per day. Thus increasing the number of non-exotic breeds does not improve milk yield. One would recommend all dairy farmers to own exotic dairy cows or at least cross breeds of good quality dairy cows like the jersey and friesian which adapt well to the country's climatic conditions in this way milk production levels will improve in the country.

There is a significantly positive relationship between milk yield and distance at $10 \%$ level to the market, that is, distance to the market increases with milk yield. This can be explained by SDB farmers who produce the highest milk yields and prefer selling it in cities near their working stations rather than farm gate or rural communities where their farms are situated. Thus, as the amount of daily milk yield increase the chances of the dairy farmer to sell at the farm gate are reduced and the need for travelling to sell dairy produce rises.

Daily milk yield is negatively and significantly related to the use of supplementary concentrates at $1 \%$ level, which means that, an increase in the numbers of farmers feeding dairy cattle with supplements by one farmer results in a decrease in the amount of milk yields by approximately 1.322 liters. This can be explained by the higher number of non-SDB farmers whose breeds are not exotic and hence less milk yields compared to the fewer number of SDB farmers who form the overall sample.

The more number of farmers not keeping dairy records the more likely to produce less milk yields. This is explained by the results presented in Table 5 which indicates a negative and significant relationship between records keeping and milk yield at 5\% level. The findings can be interpreted as a unit increase in the number of farmers who do not keep records results in a decrease of milk yields by about 1.6 litres. The study showed that about $40 \%$ dairy farmers kept dairy records of farm proceedings, most of these were the new entrants in the industry, most farmers who had more than ten years' experience did not keep dairy records but ran the industry with experience, however since most dairy farmers were the elderly, recalling medical or reproductive was a challenge.

The breeding system of farmers had a negative and significant influence on milk yield at $10 \%$ level. An increase in the number of Non-SDB farmers by one farmer will result in a decrease in milk yield by 1.9 liters. The most sampled farmers (non-SDB farmers) were using the natural bull breeding method which is thought to be less effective and hardly 
recommended in the dairy farming.

\section{Conclusion and Recommendations}

\subsection{Conclusions}

The analysis of demographic variables showed that most dairy farmers were males, married with secondary school education was the attainment, having a family size with between 5 and 9 members. The analysis of commercial indicators showed that most dairy farmers had less than four years in the industry, milked between 1 and 3 milking cows per day, which produced on average 10 litres per cow each day. The prevailing market price of milk was E10, most farmers sold their produce at the farm gate and earned less than E5,000 monthly from dairy farming. The analysis of dairy husbandry practices indicators showed that; about $53 \%$ dairy farmers practiced both stall feeding and grazing, about $50 \%$ dairy farmers practiced supplementary feeding with concentrates, about $66 \%$ dairy farmers did not plant pasture, about $57 \%$ dairy farmers used the natural bull service for breeding, about $51 \%$ dairy farmers used appropriate milk handling equipment, about $52 \%$ dairy farmers do not keep dairy records and about $50 \%$ dairy farmers were trained on dairy farming practices.

The independent t-test for independent means showed that SDB significantly contributes to milk production in the country. The multiple regression analysis showed that the independent variables that affected milk yield were: sex, age, monthly dairy income, number of cows milked per, use of supplementary feed, keeping of dairy records, and type of breeding system influenced milk yield.

\subsection{Policy Recommendations}

Based on the results, the study suggests that since age is negatively related to milk yield, SDB dairy farming advocacy strategies should target the youth and be integrated in the education curricula from primary school level and further extended to senior level. Government should encourage the youth to participate in dairy farming by providing technical, financial and commercial support. Available farmer's training centres should be strengthened to cover dairy farm management life skills to cater for young unemployed people who could not qualify to enroll in the country's universities and colleges.

As there is a positive relationship between milk yield and for the dairy farmer. One would recommend that the SDB advocacy strategy should prioritise the high income returns received by dairy farmers which enables swift capital costs recovery.

\section{References}

Central Bank of Swaziland (2008 to 2015). Annual Reports, Mbabane, Swaziland.

Gujarati, D. \& Porter, D. (2009). Basic Econometrics (5 ${ }^{\text {th }}$ ed.). New York: McGraw-Hill.

Han, M., (2014). 8 Things You Need to Know Before Starting Your Own Dairy Farm. http://extension.psu.edu/business/start-farming/livestock/dairy/8-things-you-need-to-know-be fore-starting-your-own-dairy-farm 8/20/2016 


\section{Macrothink}

Journal of Agricultural Studies

ISSN 2166-0379

2017, Vol. 5, No. 2

ILRI. (2007). Annual Report 2007 - Markets That Work: Making a Living From Agriculture. Nairobi, Kenya: International Livestock Research Institute.

Ministry of Agriculture, (2013). Comprehensive Africa Agriculture Development Programme, Mbabane, Swaziland.

Ministry of Agriculture, (2014). Annual Livestock and Production Report, Mbabane, Swaziland.

Ministry of Agriculture, (2013). Swaziland National Agricultural Investment Plan, Mbabane, Swaziland.

Morrell, J.M. (2013). Artificial Insemination: Current and Future Trends Swedish University of Agricultural Sciences, Uppsala, Sweden.

http://www.intechopen.com/books/artificial-insemination-in-farm-animals/artificial-insemina tion-current-and- future-trends 10/01/2016

Sentumbwe, S. (2007). Intra-House Labour Allocation and Technical Efficiency Among Groundnuts Producers in Eastern Uganda. Kampala, Uganda.

Swaziland Dairy Board. (2009 to 2015). Annual Reports. Manzini, Swaziland.

Swaziland Dairy Board (2000). Requirements for Starting a Dairy Enterprise. Unpublished. Manzini, Swaziland.

\section{Copyright Disclaimer}

Copyright for this article is retained by the author(s), with first publication rights granted to the journal.

This is an open-access article distributed under the terms and conditions of the Creative Commons Attribution license (http://creativecommons.org/licenses/by/4.0/). 